\title{
A Swiss Protestant perspective on a multi-faith approach to the Swiss Army Chaplaincy
}

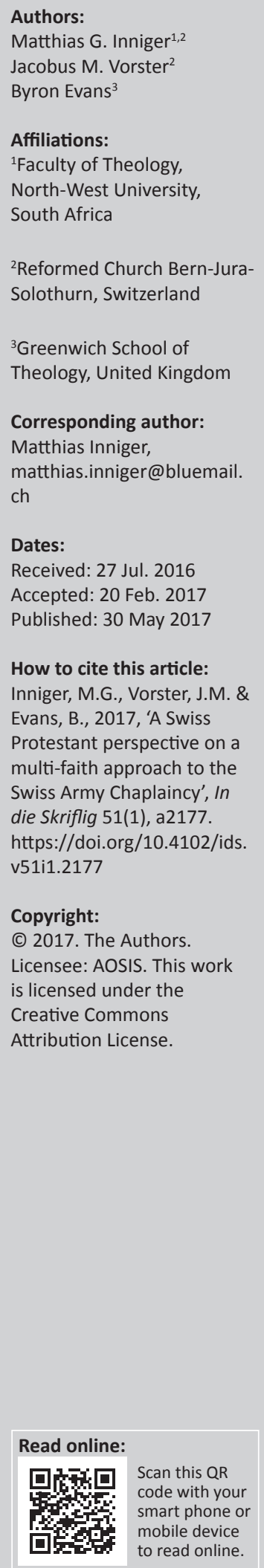

This article addresses issues of multi-faith army chaplaincies; specifically the issue of how chaplains can remain true to their own faith in a multi-faith care service. The issues addressed are relevant for chaplains and interested readers worldwide, even if this article focusses specifically on challenges in the context of the army chaplaincy of Switzerland. Due to the demographic development in Switzerland, a growing number of Muslims serve in the Swiss army. As a result, the Christian chaplaincy of the Swiss army is being challenged by increasing demands regarding Christian-Muslim dialogue. The chaplaincy asks whether or not it should involve Muslim chaplains and whether or not it should develop from a Christian one-faith to a multi-faith approach. The article at hand responds to these questions by referring to the previously published research by the same author (Inniger 2016) which provides appropriate answers to these questions. This research first identified theological-ethical principles that are valid in the Swiss Protestant church context regarding Christian-Muslim dialogue by means of an in-depth study of documents. It showed through an extended evaluation that the identified dialogue principles have not been implemented adequately in the context of the Swiss Army Chaplaincy. This research argues that Swiss Protestant churches only remain true to their principles in this field of work if they support the implementation of the identified dialogue principles. This research provides a proposal for an approach that would develop the care service of the Swiss army from a Christian one-faith to a multi-faith chaplaincy that includes, as a matter of course, the involvement of Muslim chaplains. Based on this research, this article points out that Protestant chaplains are able to remain true to their specific faith tradition, even if they do become involved in a multi-faith chaplaincy.

\section{Challenges facing the Swiss Army Chaplaincy regarding Christian-Muslim dialogue}

\section{Problem statement}

The Swiss army is a militia army, which consists largely of non-professional officers and soldiers. Given that the military service is mandatory for all young Swiss citizens in this militia system, the composition of the troop mirrors the composition of the Swiss society. This also applies to the religious affiliation of the troops, because the composition of the troops mirrors the religious landscape of Switzerland. This composition evolves due to migration, which influences demographic, cultural and religious changes. The increasing religious diversity of the troops notwithstanding, all chaplains are Christians and belong exclusively to the Swiss Catholic, Swiss Protestant and the Swiss Christ Catholic churches. ${ }^{1}$

In contrast to other army chaplaincies, the Swiss Army Chaplaincy does not usually provide opportunity for collective religious practice during the recruit school and the repetition courses, because the officers and the soldiers go home on the weekends. Practising religion in a collective sense by overseeing rituals is therefore not the duty of the Swiss army chaplains. Officers and soldiers meet their needs regarding collective religious practice during their free time. Collective practice of religion becomes a need in the context of foreign deployments. Because the Swiss army is rarely involved in foreign deployments, one can conclude that collective religious practice is not a relevant task of the Swiss Army Chaplaincy. Only in rare situations do chaplains address the troops, for example when presenting their service or during the 'Word of the day' in the morning before training starts or during promotion ceremonies. On such occasions, the Swiss army chaplains should try to speak in an inclusive way to address officers and soldiers of all faiths and none.

1.Of the Swiss population, $38 \%$ belong to the Catholic and $26.2 \%$ to the Protestant church (Schweizerische Eidgenossenschaft 2016). Only 12000 of the more than 8 million citizens of Switzerland belong to the Christ-Catholic Church (Christkatholisch 2016). These three churches are involved in the Swiss Army Chaplaincy. Chaplains of Free Churches and of the Anglican, the Orthodox and the Lutheran churches are not approved for this service as are the chaplains of Jewish, Muslim, Hindu and other religious communities. 
What are the main tasks of the chaplains of the Swiss army if collective religious practice is not necessary? Officers and soldiers address their private and army-related problems to the chaplains. This personal counselling is the main task of the chaplains. Swiss army chaplains advise those who seek help. Very seldom do officers and soldiers have ethical or spiritual concerns or questions regarding the implementation of religious rights and individual religious practice. The majority of concerns, however, are practical day-to-day issues that are not related to religion and faith. These questions require openhearted chaplains who are able to dispense advice in a pragmatic and spontaneous fashion. Such problems concern troubles at home, professional sorrows (since soldiers are, for the most part, engaged in a civilian profession both during and after the military service) and problems concerning coexistence in the army.

Even if the majority of problems and concerns are not faithspecific, issues arise regarding whether or not Christian chaplains can care for Muslim officers and soldiers in all situations and whether or not the involvement of Muslim chaplains would be a gesture of respect for the increasing number of Muslims in the Swiss army. Therefore, the involvement of Muslim chaplains is currently being debated, together with the question of whether or not this chaplaincy should develop from a Christian one-faith to a multi-faith care service. Of course, the debate considers not only Christian-Muslim relations, but also interreligious issues in general. What applies for Christian-Muslim issues applies for all interreligious relations in this chaplaincy. The involvement of Muslims in the chaplains' team is only the specific focus because of the vigorous political discussion and the demographic topicality. While the Jewish $(0.25 \%)$, Buddhist $(0.3 \%)$ and Hindu $(0.5 \%)$ population is small (Universität Luzern 2014), the Muslim population has permanently increased in the last decades to almost $6 \%$ (Ackerl 2007:97). Since the Swiss Muslim population is young, the number of Muslims in the Swiss army can be estimated to make up as much as 10\% (Inniger 2016:452).

This article presents the core of the research done for the published dissertation by the same author A theological-ethical evaluation of the Christian-Muslim dialogue in the Swiss Army Chaplaincy (Inniger 2016). This research considers the current problems regarding religious diversity from a Swiss Protestant point of view. It points out that, from the theological-ethical principles' point of view, which are valid tools to use in the Swiss Protestant church context regarding Christian-Muslim dialogue, a change from a Christian one-faith to a multi-faith care chaplaincy service is possible or even necessary. The study furthermore shows that a Protestant chaplain could remain true to his or her faith, even if he or she were involved in a multi-faith chaplaincy.

\section{The Debate}

The Swiss Army Chaplaincy has not yet evaluated how Swiss army commanders or the representatives of Muslim Swiss umbrella organisations or Muslim officers and soldiers consider this situation. Instead of evaluating this new situation, the Christian chaplaincy has, until now, only rejected the idea of involving Muslim chaplains. The research study (Inniger 2016), which gave rise to this article, enters into this debate and makes the arguments of the Swiss Army Chaplaincy against Muslim involvement more objective. The arguments are discussed in view of the evident ChristianMuslim challenges in this care service and of the demographic development in Switzerland.

One argument of the Swiss Army Chaplaincy is that Christian chaplains care competently for all officers and soldiers (Schweizer Armee 2013:216). Consequently, the presence and expertise of Muslim chaplains are simply not necessary. However, a significant portion of contemporary research regarding this issue questions this argument. Cimşit (2013:22), for example, states that pastoral care for Muslims provided by non-Muslim chaplains is largely adequate, but he also mentions that this service can reach its limits if faith-specific questions or problems arise. The extended evaluation of the research (Inniger 2016:89-183) confirms that in specific situations, for example, if a Muslim soldier mourns a family member, is involved in an accident or has specific questions regarding the implementation of religious rights, the involvement of Muslim chaplains would be necessary (p. 156). Therefore, the argument that Christian chaplains can care for Muslim officers and soldiers in all situations should be reconsidered. Another argument of the Swiss Army Chaplaincy is that Muslim soldiers do not consider this service necessary (Inniger 2016:366). Seyyar (2013:87), however, contradicts this and states that Islam provides pastoral care for all social groups in the same way as all other religions. According to Seyyar (2012:38-41), caregiving has been practised in Islamic tradition since the times of Muhammed. Swiss Muslim leaders confirm that an Islamic care service is the logical consequence of the charitable pillars of Islam, because, caring for others, is a crucial Islamic duty (Inniger 2016:369). The evaluation of the research (Inniger 2016:340) confirms that the majority of Swiss Muslims consider this service essential and would like Muslim caregivers to be involved in this service too. The argument that Muslims do not consider this care service essential should also be revised. One further argument brought forward by the Swiss Army Chaplaincy against Muslim involvement is also debated in the research study of Inniger (2016:366): Representatives of the Swiss Army Chaplaincy consider the lack of public and legal recognition of Muslim organisations in Swiss cantons ${ }^{2}$ as another argument against Muslim involvement in the chaplains' team. Muslim organisations in Switzerland, until now, lacked public and legal recognition compared to Catholic, Christian-Catholic and Protestant churches, which enjoy this recognition in the majority of Swiss cantons. Nevertheless, this argument must be rebutted; first and foremost because of discriminatory aspects: it is in the interest of the Swiss Federation to avoid such discrimination against the second largest religion in Switzerland (Schweizerische Eidgenossenschaft 2013, art. 8). Rather, it is in the best interests 2.The districts of Switzerland are called 'cantons'. 
of the Swiss Federation to integrate minorities, including religious minorities (Schweizerische Eidgenossenschaft 2015). If the Swiss Army Chaplaincy involved Muslim chaplains, this would be a helpful measure to promote integration. Therefore, lack of recognition is not a reason for excluding Muslims in the Swiss army chaplains' team. Lack of recognition is, in fact, a reason for including them, because inclusion of Muslims avoids discrimination and supports integration. According to Loretan, Weber and Morawa (2014:65), any form of involvement of Muslims is an opportunity to promote cooperation between the state and Muslim organisations and to further future recognition.

The research (Inniger 2016), presented in this article, does not only focus on the rejection of the arguments against Muslim involvement put forward by the Swiss Army Chaplaincy. It also aims to contribute to this debate by suggesting a new approach to this chaplaincy from a Swiss Protestant perspective to offer solutions for the Christian-Muslim challenges in this chaplaincy.

\section{A Swiss Protestant perspective regarding Christian-Muslim challenges in the Swiss Army Chaplaincy}

\section{A Swiss Protestant perspective}

The research (Inniger 2016) to which this article refers, takes a Swiss Protestant perspective. ${ }^{3}$ It asks whether or not the involvement of Muslims in the chaplains' team and the change from a Christian one-faith to a multi-faith chaplaincy should be promoted if one takes a Swiss Protestant perspective. Such a perspective involves respecting Swiss Protestant principles regarding Christian-Muslim dialogue.

Through an in-depth study of the Swiss Protestant official statements, arguments, guidelines and practices regarding Christian-Muslim dialogue, five dialogue principles have been identified (Inniger 2016:38-63). The consideration of these principles ensures respect for the Swiss Protestant perspective. These dialogue principles can be defined as follows within the context of Christian-Muslim dialogue in the Swiss army (Inniger 2016:87):

- The Swiss Army Chaplaincy is committed to the Christian-Muslim dialogue (principle 1).

- The Swiss Army Chaplaincy, above all, sees unifying commonalities instead of separating factors between Christians and Muslims (principle 2).

- The Swiss Army Chaplaincy respects Muslims and Islamic attitudes, concerns and needs (principle 3).

3.By taking a Protestant perspective, the presented research of Inniger (2016) by no means implies the adoption of an anti-ecumenical position. Ecumenical cooperation is well-established in this care service, and the author of this study is sure that the Swiss Catholic, Christian-Catholic and Protestant churches will together find ways of contributing to interreligious dialogue in the Swiss Army together find ways of contributing to interreligious dialogue in the Swiss Army Chaplaincy. The reason for this specific Protestant perspective is ecumenical
sincerity and respect. The author wants to avoid an approach in which the Catholic and the Christian-Catholic partners of the Swiss Army Chaplaincy feel Catholic and the Christian-Catholic partners of the Swiss Army Chaplaincy fee
patronised by a researcher who has a Protestant point of view. An ecumenical patronised by a researcher who has a Protestant point of view. An ec
perspective would have required an ecumenical research group. (p. 13)
- The Swiss Army Chaplaincy wants to empower Muslims to stand by their religious conviction, and therefore it considers the concerns of Muslims in this care service (principle 4).

- The Swiss Army Chaplaincy aims to build bridges between Christians and Muslims in the context of the Swiss army (principle 5).

From the perspective of these dialogue principles, this article aims to contribute to the on-going debate by evaluating the current state of the Christian-Muslim dialogue in the Swiss Army Chaplaincy and by eventually recommending a new approach to Christian-Muslim and interreligious cooperation by implementing the previously identified dialogue principles in the context of the Swiss Army Chaplaincy.

\section{An evaluation of the current state of Christian- Muslim dialogue in the Swiss Army Chaplaincy}

Ecumenical, interreligious and governmental partners and partners of other national army chaplaincies confirm the validity of these dialogue principles (Inniger 2016:59-62). The research study, at the basis of this article, evaluates whether or not the relevant dialogue principles of the Swiss Protestant tradition regarding Christian-Muslim dialogue are implemented in the context of the current Swiss Army Chaplaincy (Inniger 2016:89-183). The result of the evaluation, carried out among Muslim Swiss army officers and soldiers, Swiss army commanders and chaplains with national and international experts, is that these dialogue principles have not been fully respected and implemented. The identified gaps between the current state of Christian-Muslim dialogue in the Swiss Army Chaplaincy and the Swiss Protestant dialogue standards evince specific shortcomings regarding the implementation of these dialogue principles. These shortcomings concern, for example, the lack of specific Islamic know-how among Christian chaplains and the lack of specific support for Muslim personnel in the matter of the implementation of religious rights and of spiritual care. Moreover, they concern the lack of trust of Muslim army personnel regarding this Christian care service, not least because of the Christian monopoly and the specific Christian credo of this service, which states that all Swiss army chaplains witness, by accomplishing their task, 'Jesus Christ in today's age of pluralism' (Schweizer Armee 2014). Inniger (2016:149-167) shows that shortcomings also concern the marginalisation, systematic rejection and exclusion of Muslim caregivers from this chaplains' team and, subsequently, a lack of sensitivity regarding religious minorities in the Swiss army, over and above the lack of interreligious sensitivity in this field of work. The implementation of the abovementioned Swiss Protestant dialogue principles falls short. One can conclude that the evaluation clearly shows that Christian-Muslim dialogue in the Swiss Army Chaplaincy is inadequate. Both a dialogue between the Christian chaplaincy and Muslim umbrella organisations, as well as a dialogue between those responsible for this chaplaincy and Muslim officers and soldiers, are lacking. This situation should be reconsidered. Recommendations regarding the improvement 
of the situation are necessary if the current Christian-Muslim dialogue in this chaplaincy is to correspond with Swiss Protestant dialogue standards.

\section{Recommendations for the improvement of Christian-Muslim dialogue in the Swiss Army Chaplaincy}

Inniger's research (2016) does not focus on highlighting shortcomings. It rather recommends implementing Swiss Protestant theological-ethical principles for Christian-Muslim dialogue in the context of the Swiss Army Chaplaincy. This implementation offers an approach to the Swiss Army Chaplaincy that adequately promotes Christian-Muslim and interreligious dialogue. This is a multi-faith approach that aims to demonstrate the chaplains' commitment to ChristianMuslim and interreligious dialogue as beneficial (principle 1). The principle of unifying commonalities will be emphasised in such a way that all officers and soldiers will feel represented in this chaplaincy (principle 2). Moreover, this approach emphasises the principle of respect in such a way that the missionary credo of this chaplaincy is reconsidered. It establishes rules regarding inclusive public speech and supports the participation of Muslim and other non-Christian caregivers (principle3). Furthermore, this approach implements the principle of empowerment in such a way that Muslim officers and soldiers have the same access to spiritual care (principle 4). Finally, this approach aims at developing a multi-faith Swiss Army Chaplaincy in which bridge-building activities between officers and soldiers from all faiths can be realised (principle 5).

\section{The recommended multi-faith approach for the Swiss Army Chaplaincy Preliminary remarks regarding the recommended multi-faith approach}

The implementation of the identified dialogue principles will lead to a proposal for a new multi-faith approach to the Swiss Army Chaplaincy - one that meets the requirements of Swiss Protestant dialogue standards and promotes ChristianMuslim dialogue. ${ }^{4}$

The following preliminary remarks explain the basic idea of the multi-faith approach recommended in this research (Inniger 2016:204-231). The approach requires that the chaplains of the recommended multi-faith Swiss Army Chaplaincy are implicitly committed to Christian-Muslim and to interreligious dialogue in general (principle 1). Moreover, the recommended approach stresses the importance of formulating a commitment of this care service that includes the terms humanity, respectful coexistence and spiritual well-being (see next section). These terms not only highlight important considerations with regard to the

4.As mentioned in the problem statement of this article (see above) the focus is not only on Christian-Muslim relations, but also on other interreligious relations. What is valid regarding Christian-Muslim relations applies to all interreligious relations in this chaplaincy. The involvement of Muslims is only the specific focus because of the this chaplaincy. The involven
demographic topicality. coexistence of people and spiritual well-being, but they also ensure that the relevant dialogue principles will be respected and implicitly implemented. The term humanity emphasises our common humanity insofar as this chaplaincy does not differentiate between service for Jews, Hindus, Christians, Muslims, Buddhists, atheists or humanists, but rather sees it as a service for all human beings. This care service is a humanto-human service that respects the existence of the unifying commonalities of all human beings (principle 2). Furthermore, the reference to 'respectful coexistence' emphasises that diversity is respected and intercultural and interreligious awareness is promoted in the context of this chaplaincy. 'Respectful coexistence' is necessary in an army where people live so closely together. The term respectful coexistence implicitly defines the identified dialogue principles of respect (principle 3) and building bridges (principle 5). The term spiritual well-being is, above all, the main concern of any chaplaincy and, of course, of the Swiss Army Chaplaincy. The intention of the Swiss army to provide appropriate care and to consider the spiritual needs of all officers and soldiers is included in this term. The essence of the dialogue principle of empowerment resonates (principle 4). If the recommended multi-faith approach of the Swiss Army Chaplaincy is designed in such a way that this care service supports all officers and soldiers to experience humanity, respectful coexistence and spiritual well-being, the identified dialogue principles are being implemented and the purpose of this chaplaincy will be fulfilled.

\section{The Commitment}

Inniger (2016) suggests the following commitment regarding a new multi-faith approach to the Swiss Army Chaplaincy:

\footnotetext{
The Swiss Army Chaplaincy is committed to the spiritual wellbeing of all officers and soldiers. It respects freedom of belief and conscience, and, therefore, the individual faith and life approach of every officer and soldier. The faith tradition of chaplains shall, however, remain in the background because this service is a human-to-human-service. Furthermore, the Swiss Army Chaplaincy is committed to our common humanity, to respectful coexistence, to religious diversity, to non-proselytising, and to ecumenical and interreligious dialogue, moreover, to Swiss law, human rights, human dignity and the values of justice, freedom, equality, solidarity and tolerance. (pp. 211-212)
}

\section{Providing faith-specific care}

The recommended approach of a multi-faith Swiss Army Chaplaincy provides a service to all officers and soldiers. The tasks of the recommended chaplaincy will in general concur with the traditional tasks of the current Swiss Army Chaplaincy, except that these tasks will be carried out by members of a multi-faith chaplains' team and not by Christian chaplains alone. Although the research (Inniger 2016) recommends developing a multi-faith approach, it resists the temptation of providing a service in which, for example, Christians care for Christians and Muslims care for Muslims. It is important to point out that the approach is clear on the fact that the assigned chaplain - regardless of his or her religion - cares for all officers and soldiers of the specific 
military units and schools regarding day-to-day-issues. Faith-specific care would only be provided in very specific situations, which are clearly defined in the following section.

It is possible to renounce faith-specific service with regard to day-to-day-issues, because, observing officers and soldiers of the Swiss army, can meet their specific religious or spiritual needs on free weekends. They also have the opportunity to take leave for certain periods during training if they have specific religious needs. Moreover, practicing Christians and Muslims may be surprised and impressed by the openmindedness and professionalism of a chaplain of another faith. The organisation of a chaplaincy in which faith-specific care is provided, would not be possible from a practical viewpoint. What is more, a faith-specific approach to care would not have the effect of uniting the troops, but would rather divide them. Over and above this, such a practice will raise the question of who is Christian and who is Muslim. ${ }^{5}$ Non-practicing Christians and Muslims are interested in receiving practical and helpful guidance. If they have been distanced from religious institutions, communities or churches, they feel relieved that they are not categorised according to their specific religion. They are just glad that they are respected as humans if they can find an open-hearted chaplain who listens to them in a professional way. For the majority of concerns of officers and soldiers seeking help and advice, the religious affiliation of the chaplain is of subordinate importance. It has a confidence-building effect on practicing and non-practicing Christian and Muslim officers and soldiers if they know that their religion is represented in the chaplains' team.

The claims for faith-specific care regarding day-to-day issues would, above all, contradict the intentions of Protestant faith, which considers God's unconditional and universal grace (Inniger 2016:18-21) and the universal dimension of religion. Faith-specific care would involve a diminishing of faiths and religions by banishing them to narrowly defined communities. If chaplains only care for officers and soldiers of the same faith, universal religions would be reduced to religious groups and subgroups. In consequence, faith-specific chaplains would service only the members of these groups and subgroups. The religions represented in the chaplains' team are, however, not religious groups, but universal religions with a universal message, calling people together in the name of peace and love. They are dedicated to humanity, respectful coexistence and the spiritual well-being of all human beings. In the name of these universal religions, chaplains are able to provide the recommended human-tohuman service.

\section{The tasks}

If the Swiss army decides to establish a multi-faith chaplaincy in line with the recommendations of this article, all chaplains will be assigned to different military units and schools. They will share, regardless of their religious affiliation, the general tasks of this chaplaincy. A first task of chaplains will be their involvement with the military staff and in military life, establishing contact and building confidence in a military context. In this context, the chaplains will care for officers and soldiers with regard to concerns such as implementing religious rights (facilitating the implementation of religious rights and the religious practice of individuals, and advising commanders regarding these issues), social concerns (daily life in the army, problems with superiors, questions regarding a military career, mobbing, writing a will), personal concerns (personal or professional development, friendships, relationships, family, sorrows), ethical concerns (ethical questions, operations) and spiritual concerns (needs and prayer). Caring also includes a general triage function. ${ }^{6}$ This means that chaplains should, in a spirit of empowerment, recommend that personnel contact a doctor, psychologist, social worker, the commander or the head of the company in which they serve. Furthermore, the general tasks of chaplains will include presenting the chaplains' service and visiting troops, soldiers in training, those under arrest and those in the infirmary. These tasks will also include speaking publicly, for example to deliver the 'Word of the day' in the morning during promotion ceremonies, flag presentations or when closing a military unit as well as at other occasions of meetings and gatherings. Cooperating in working groups and foreign deployments will be necessary as well as attending refresher courses and chaplains' gatherings. Supporting the Swiss Army Care Team and providing help in emergencies is also an important general task for chaplains who are specifically trained for this.

Although the recommended approach avoids faith-specific care services regarding the day-to-day concerns of officers and soldiers, it considers that, in exceptional cases, the tasks of chaplains can be better carried out by faith-specific chaplains. In a multi-faith chaplaincy, these chaplains will be available. These specific situations should be clearly defined: chaplains will provide faith-specific advice if, for example, commanders or chaplains' colleagues transfer faith-specific questions on behalf of officers and soldiers. They will advise indirectly via the chaplain or the commander. ${ }^{7}$ If officers and soldiers have faith-specific concerns in connection with grief and death, assigned chaplains or commanders could facilitate a face-to-face meeting with a faith-specific chaplain. Furthermore, chaplains would be involved in faith-specific tasks when overseeing rituals in connection with military accidents and incidents. Finally, chaplains would also be involved in faith-specific tasks when issuing faith-specific documentation and information. However, all the tasks of a chaplaincy will be covered.

6.Army chaplains in Switzerland have this triage function, because they can be contacted without the permission of commanders and other officers. Because of this uncomplicated and easy access, Swiss army chaplains are contacted frequently and, more often than not, they recommend that officers and soldiers seek further help.

7.Muslim officers and soldiers sometimes do not contact Christian chaplains, because they know from experience that they cannot adequately meet Islamic standards. For kn For example, a Muslim may want to know from a chaplain how they can deal with ritual cleansing outside camps (Inniger 2016:341-342). If, however, this specific situation is not mentioned in the information sheets, the chaplain of this Muslim soldier could contact his or her Muslim colleague to ask his or her opinion and suggestion. 


\section{The chaplains' qualifications}

The recommended multi-faith Swiss Army Chaplaincy will require the following qualifications for chaplains: first, the candidates must give proof in an assessment that they understand and accept the commitment and function of the Swiss Army Chaplaincy. They must understand the advantages of a multi-faith chaplaincy. They must be fully motivated to be involved in this chaplaincy. Furthermore, the candidates must give proof that they are able to change perspective $^{8}$ as necessary, and that they have a good knowledge of the Swiss religious landscape and of the implementation of religious rights. Second, the candidates must be theological professionals of an officially and legally recognised Swiss church (Swiss Catholic, Christian-Catholic or Protestant), or of the Orthodox, Lutheran or Anglican churches, or of a free Swiss church, or of a Swiss Jewish, Muslim, Buddhist, Hindu or other religious organisation under private law. The candidates should be recommended by their churches or by their religious organisations for this service. Third, the candidates must give proof of their religious and theological training and expertise by possessing a Master's degree in Theology, Religious Science, Interreligious Studies, Islamic or Jewish Studies, or additional fields of study. The candidates must also give proof of their training and expertise regarding counselling and care. The experts of the Swiss Army Chaplaincy will decide during the course of the application and assessment procedure whether or not the candidate has enough qualifications to start the chaplains' training. Fourth, the candidates have to provide evidence of experience regarding military service in the Swiss army. They must at least have passed the recruit school successfully. Moreover, they must qualify as fit for military service. Fifth, the candidates have to provide references, work certificates and a good official reputation. Furthermore, they have to be fluent in one of the four Swiss national languages (German, French, Italian or Rhaeto-Rumansh). In addition to this, they must have a good working knowledge of at least another Swiss national language.

\section{The Advantages}

Inniger (2016) recommends that the Swiss Army Chaplaincy should evolve from a Christian one-faith to a multi-faith care service in order to promote Christian-Muslim and interreligious dialogue and in order to involve Muslim and other non-Christian chaplains. The advantages of the recommended multi-faith approach to such a chaplaincy are obvious. First, every officer and soldier knows that the assigned chaplain belongs to a chaplains' team in which chaplains are working closely together with colleagues of every religious affiliation. Soldiers of different faiths whether they are practicing or non-practicing - know that their religion is represented in the chaplains' team. This awareness builds confidence. Second, Swiss army chaplains from every faith carry out their tasks to the benefit of officers and soldiers of all faiths. This can be compared with the situation of patients in hospitals who do not ask whether the operating surgeon is a Christian or a Muslim. They trust in the surgeon's professionalism. In this sense, officers and soldiers can confidently trust that their assigned chaplains are committed to a human-to-human care service. Third, it builds confidence if officers and soldiers of every faith know that the established information sheets of the Swiss army regarding individual religious practice (prayer times, food regulations and additional leave for religious feasts) have been authored by experts of their own faith. The suggestions on how to implement religious rights and how to individually practice religion under specific circumstances stem from chaplains of one's own faith. Fourth, officers and soldiers know that, if faith-specific questions arise, their assigned chaplain or their commander can contact a faith-specific chaplain who can advise the assigned chaplain or the commander regarding specific questions and situations. These advisors are integrated into the military service and serve in different military units or schools. Fifth, officers and soldiers know - and this also makes a difference - that a faith-specific chaplain can be called on site if an accident occurs, if a soldier loses a family member and is grieving. Also in the case of faith-specific ceremonies, a faith-specific chaplain is available. In such situations, the persons affected or their related parties should express their wishes regarding the religious affiliation of their chaplain.

One can conclude that the multi-faith approach to the Swiss Army Chaplaincy presented in this research (Inniger 2016) is based on Swiss Protestant standards regarding ChristianMuslim dialogue. The implementation of these principles makes it possible to establish an approach to a multi-faith chaplaincy that meets the requirements of Swiss Protestant churches regarding Christian-Muslim dialogue.

\section{Remaining true to one's own faith}

Based on the presented research (Inniger 2016:232-241), the article at hand emphasises that chaplains involved in a multifaith chaplaincy are able to remain true to their own faith. Swiss Protestant army chaplains, for example, remain true to their Protestant faith. The recommended approach emphasises that all chaplains involved in a multi-faith chaplaincy have their own faith-specific traditions, their specific spiritual resources and their specific motivation. Protestant chaplains in the Swiss militia army, for example, minister on Sundays to their own congregations and the Bible remains, as a matter of course, the basis of their faith and service.

What are the faith-specific resources of Swiss Protestant chaplains who are involved in a multi-faith chaplaincy that provides a human-to-human service and in which the chaplain's faith remains on the background? Regarding this

9.I hope that readers worldwide, who are interested in today's development of chaplaincies and specifically of army chaplaincies, will find new perspectives when considering the development and the evaluation of the Swiss Army Chaplaincy. Furthermore, I hope that the information of this specific article will add value for readers worldwide, because the profiling of Christian chaplains in a multi-faith chaplaincy might be of major interest for professionals involved in multi-faith chaplaincies. 
issue of faith-specific resources, the presented research (Inniger 2016:232-241) suggests that all chaplains of the multi-faith Swiss Army Chaplaincy should discuss this question in a spirit of ecumenical and interreligious dialogue. It states that even if the chaplains of all denominations and faiths have their own background and faith-specific resources, this research identifies - with all due respect to those of other faiths and religions - only resources and contributions of Christian and specifically of the Protestant faith.

Inniger (2016:232-241) points out how the Christian-biblical background and the Protestant-specific resources nourish, inspire and empower the Swiss Protestant chaplains in the Swiss army and how this background and these specific resources define the chaplains' attitude, also with regard to involvement in a multi-faith chaplaincy. Protestant chaplains share these resources with other Christian chaplains. The enumeration of Christian-biblical and specific Protestant resources, regarding this service, does not claim to be complete, but it points out what this research understands regarding faith-specific resources. Even if these resources remain in the background when caring for others, they influence the chaplains' attitude:

\section{- Faith in God, the Creator}

One resource of Christian chaplains is faith in a God who created all human beings (Is 45:18). For Christian chaplains who will be involved in a multi-faith Swiss Army Chaplaincy, this faith fosters the view that all officers and soldiers are part of God's humanity. On this basis, Christian chaplains value all officers and soldiers equally, that is, as equal creatures of God.

- Faith in God, the good Shepherd

Another resource is faith in God, the good Shepherd (Ps 23:1-4). This resource does not imply that Christian chaplains speak about their faith experience regarding the good Shepherd; rather this faith is embodied in the chaplains' attitude. Army personnel who contact Christian chaplains in difficult times might feel comforted if chaplains are able to communicate their faith that every human being is, non-verbally, cared for by God. Christian chaplains will, instead of speaking about personal faith, respectfully ask the soldier a question such as: 'Have you ever experienced in your life things that make you calm and confident?' Very often, soldiers begin to speak in such moments of how they have dealt with similar situations or from what or where they have drawn support. Sometimes they mention the faith of their grandmother or the charisma of a teacher or a neighbour from earlier times that has inspired them. Very often, such starting points can be used for activating the specific resources of those seeking help and advice.

- The good Samaritan

The parable of the good Samaritan (Lk 10:25-37) can be seen as another resource for Christian chaplains. It refers to faith in Jesus, who did not distinguish between the religions of caregivers and those who receive their care. In consequence, Christian chaplains may consider care for each other as a human-to-human service. Therefore, this parable would be an outstanding resource for Christian chaplains working in a multi-faith Swiss Army Chaplaincy. The man going down from Jerusalem to Jericho was a human being. The Samaritan was a human being too. Was the man attacked by robbers concerned with the religion of the Samaritan? Did the Samaritan concern himself with the religion of the man attacked by the robbers? This human-to-human service would be a role model for Christian Swiss army chaplains in a multi-faith chaplaincy. According to Schipani (2009:66), Jesus teaches in this parable that caregivers 'engaged in interfaith situations may discover new dimensions of meaning and love through caring especially well for those who are different or a "minority"'. Schipani (2009:66) adds that this parable helps to rediscover the Gospel's truth by being open to the faith of others. This resource points out the understanding of Jesus, who calls for loving care among all human beings.

- The last judgement

A further Christian resource can be seen in the parable of the last judgement (Mt 25:31-46) in which Jesus states that whatever we do for 'one of the least of these brothers and sisters of mine' (Mt 25:40), we do for Jesus. This resource would also support those Christians serving as chaplain in a multi-faith Swiss Army Chaplaincy. Following Schipani (2009), this parable helps Christian chaplains to see and to serve Jesus in interfaith situations:

Pastoral caregivers may recognize and honor their daily walk into/within sacred places because visiting the sick strangers and their relatives (other-than-Christian) is an occasion to care for "one of the least of these..."; instead of trying to "bring Jesus" to the care receivers, they can confidently expect to encounter Christ in them and to care for Christ, as it were, through them. (p. 66)

If chaplains have confidence in the fact that they are giving care in the Spirit of Christ, gives serving as a Christian chaplain in the multi-faith Swiss Army Chaplaincy full meaning:

- Belief in Easter

Another Christian-biblical resource is belief in the resurrection of Christ (Lk 24:6a). Even if Christian chaplains do not speak about this, they believe that the resurrection signifies that God's encouragement of life is stronger than all tribulations and even stronger than death. Why should belief in Easter not be included as a resource regarding Christian involvement in the multifaith Swiss Army Chaplaincy? As long as Christian chaplains do not proselytise in the secular context of the Swiss army, they remain true to themselves if they believe in the resurrection of Christ and if they consider and experience their faith as an important source of strength and hope for their service.

The research (Inniger 2016) on which this article draws, identifies further resources that are specifically connected to Protestant faith. These resources are cited below together with the approaches suggested by Protestant practical theologians. They will inspire Protestant chaplains also to contribute to this service. Moreover, these specific Protestant 
resources will help to identify an appropriate Protestant approach to caregiving in a multi-faith Swiss Army Chaplaincy:

\section{- Sola gratia}

This phrase refers to faith in God's grace, which brings about salvation and justification without human contribution. In view of this perspective, Protestant chaplains see all army personnel as beneficiaries in light of God's unconditional and universal grace. Following this perspective regarding God's unconditional and universal grace, Bernhardt (2007:46) confirms that all people have salutary relations with God. ${ }^{10}$ This view makes Protestant army chaplains confident regarding their involvement in a multi-faith chaplaincy, because they have no need for proselytising; rather they can concentrate on their human-to-human service. The light of God's grace shines on all officers and soldiers.

- Solus Christus

Following these considerations, the Protestant researcher Walther (2009:274) asks how Protestant chaplains should deal with the doctrine of solus Christus. Walther (2009:274) refers first to the biblical story of Noah's ark and God's covenant with Noah (Gn 6-9) and states that chaplaincy, in a multi-faith context, can be seen as 'a happening under the rainbow'. If Protestant chaplains commune with people from outside of their own faith tradition when caring for them, and when caring together with chaplains of other faiths in the same chaplaincy, this is seen as an activity that happens under one rainbow and which can be interpreted as a human covenant revealing God's peace (Walther 2009:274). In this context, Walther does not see involvement in a multi-faith chaplaincy as a contradiction to the exclusive claim of the doctrine of solus Christus. She (Walther 2009:274) states that Protestants can eschatologically expect God to relieve the soteriological tension between the Reformation doctrine of solus Christus and the multi-faith reality by having reasonable respect and appreciation for traditions from outside the Christian faith tradition and by relying on the healing and saving power that exists within them. Chaplains who eschatologically expect God to relieve this soteriological tension live in the soteriological hope that makes involvement in a multi-faith care service possible as well as the need to engage in mission unnecessary.

- True being-in-the-world.

Lartey (2003:175-177) contributes further by stating some perspectives that are helpful for Protestants in multi-faith chaplaincies. He (Lartey 2003:175) mentions the term kenosis [self-emptying], which means the process of 'emptying'. Lartey states that it belongs to the core of Christian understanding that Christ's emptying of himself in the incarnation is the heart of the Gospel, as celebrated in Philippians 2:5-8. He (Lartey 2003:175-177) refers to the fact that kenosis is the quintessence of the life of God, who is constantly engaging in acts of giving and of emptying himself for humanity. Lartey (2003) states

10.For Bernhardt (2007:46), such relations are essential if God's plan for salvation is unconditional and universal. that even if the origins of the term pastoral care are Christian; pastoral care should no longer refer exclusively to Christian faith and care, because kenosis has further implications:

It is my view that the time has come for the essence of "pastoral care" to be freed from the captivity of its "selfhood" in terms of origin, in order that it can engage in real terms with the pluralism of the current world. Will it by so doing lose its essence and identity? I think not, for it is in such self-emptying that its true being-in-the-world may be realized. It is in giving away its very self that its truest goals will be achieved. Pastoral caregivers need the humility and trust in the divine presence that will enable us not to hold on tenaciously and obsessively to the symbols of office. Instead will flourish an "other" directed practice that respects difference and seeks to give itself away in loving service. (p. 176).

According to Lartey (2003:177), the process of kenosis frees the believer from old care concepts and helps the person to develop openness to the experience of 'God's creative genius [that] challenges and calls us out of our lazy, monotonous repetitions of sameness into the rich color of the diversity that surrounds us.' If one transfers Lartey's idea to the current inadequate interreligious situation of the Swiss Army Chaplaincy, this care service should be freed from its current captivity; rather this chaplaincy should develop openness towards interreligious dialogue. From a Protestant perspective, Protestant chaplains can therefore become involved in a multi-faith chaplaincy. In the sense of kenosis, this chaplaincy would sever ties with out-dated care models in favour of models that reflect and realise 'true being-in-the-world'. In this context, Lartey (2003) adds that incarnation theology is closely allied to the term kenosis:

The presence and activity of God is to be found in the midst of the experiences of the world ... It's a call to recognize God's presence in the various cultures and heritages of the world. It is to stand in awe of the mystery of 'otherness'. (p. 176)

Following Lartey (2003:176), the idea of incarnation allows Protestant chaplains to see, for example, the words of Jesus, who came so that 'they may have life, and have it to the full' (Jn 10:10b), in the sense that 'the fullness of life' is given to all officers and soldiers.

Based on these biblical-Christian and Protestant-specific perspectives and resources, Protestant chaplains should consider involvement in the recommended multi-faith Swiss Army Chaplaincy as 'true being-in-the-world'. One can conclude that Protestant chaplains would be able to serve in a multi-faith chaplains' team and support atheist, agnostic, anticlerical, humanist, Christian, Jewish, Muslim, Buddhist or Hindu officers and soldiers by seeing them in light of God's unconditional and universal grace and by supporting them regarding their growth into the fullness of life and its divine nature.

As mentioned in footnote 9, the article at hand aims to support chaplains worldwide regarding the issue of how 
they can remain true to their own faith in a multi-faith chaplaincy. Therefore, the article aims to launch a debate regarding the faith-specific resources of individual chaplains. It aims at pointing out that a chaplain in a multi-faith care service is neither a neutral chaplain nor an 'interreligious' chaplain, but a chaplain who remains true to his or her faith.

\section{Conclusion}

Social and demographic developments in Switzerland affect Swiss Protestant churches generally and the Protestant army chaplaincy specifically. Christian-Muslim dialogue is a specific challenge for the Swiss Army Chaplaincy in which Protestant churches are involved. This article concisely presents the published research study of the same author (Inniger 2016) that argues that Swiss Protestant churches should consider their own principles regarding Christian-Muslim dialogue in the field of the Swiss Army Chaplaincy. Respecting their own dialogue principles, implies that Swiss Protestant churches should support the evolution from a Christian one-faith to a multi-faith Swiss Army Chaplaincy in which Muslim chaplains and chaplains of other non-Christian religions could be involved and in which Christian-Muslim and interreligious dialogue could be promoted. Furthermore, this article emphasises that this development should not be seen as a risk, but rather as an opportunity. The process of establishing a multi-faith chaplaincy could even promote awareness among Protestant churches, whose wealth of resources and rich experiences could be brought to bear in a multi-faith chaplaincy. However, if Protestant chaplains would decide to cooperate in the chaplains' multi-faith team under the one rainbow of God's promise for peace, and if 'Good Samaritans' of diverse religious professions would care together for those officers and soldiers who seek advice and help, 'sincere Christian-Muslim ${ }^{11}$ dialogue in the Swiss Army Chaplaincy would no longer remain an unfulfilled vision' (Inniger 2016:252).

For indexing purposes:

- Due to demographic developments, Swiss Protestant churches are being challenged regarding Christian-Muslim dialogue. This challenge concerns, in particular, institutional chaplaincies such as the Swiss Army Chaplaincy.

11.According to the approach proposed in the research (Inniger 2016), not only should Christian-Muslim dialogue be fostered, but also general ecumenical and interreligious dialogue.
- Following the theological-ethical principles valid in the Swiss Protestant church context regarding ChristianMuslim dialogue, Swiss Protestant churches should promote Christian-Muslim dialogue in the Swiss army by supporting the transition from a Christian onefaith to a multi-faith approach. This would make involvement of Muslim and other non-Christian chaplains possible.

- Protestant chaplains, who are involved in a multi-faith army chaplaincy, remain true to their Protestant faith.

\section{References}

Ackerl, I., 2007, Die Staaten der Erde - Europa und Asien, Marix Verlag, Wiesbaden.

Bernhardt, R., 2007, Wahrheit in Offenheit. Der christliche Glaube und die Religionen, Verlag Schweizerisch Evangelischer Kirchenbund, Bern.

Cimşit, M., 2013, 'Islamische Seelsorge - Eine theologische Begriffsbestimmung', in B. Ucar \& M.

Blasberg-Kuhnke (eds.), Islamische Seelsorge zwischen Herkunft und Zukunft, pp. 13-26, Peter Lang $\mathrm{GmbH}$, Frankfurt am Main.

Christkatholisch, 2016, Bistum, viewed 5 June 2016, from https://christkatholisch. $\mathrm{ch} / \mathrm{bistum}$

Inniger, M., 2016, 'A Theological-Ethical Evaluation of the Christian-Muslim Dialogue in the Swiss Army Chaplaincy' PhD thesis, North-West University, Potchefstroom.

Lartey, E., 2003, In living color: An intercultural approach to pastoral care and counseling, 2nd edn., Jessica Kingsley Publishers Ltd., London.

Loretan, A., Weber, Q. \& Morawa, A., 2014, Freiheit und Religion. Die Anerkennung weiterer Religionsgemeinschaften in der Schweiz, LIT Verlag, Münster.

Schipani, D.S., 2009, 'Biblical foundations: challenges and possibilities of interfaith caregiving', in D.S.

Schipani \& L. Bueckert (eds.), Interfaith spiritual care: Understandings and practices, pp. 51-68, Pandora Press, Kitchener.

Schweizer Armee (ed.), 2013, Gedanken zur Armeeseelsorge. Religion und Humanität im Spannungsfeld der Armee, Vertrieb Bundespublikationen, Bern.

Schweizer Armee, 2014, Homepage Armeeseelsorge, viewed 14 December 2014, from http://www.vtg.admin.ch/internet/vtg/en/home/militaerdienst/allgemeines/ armeeseelsorge.html

Schweizerische Eidgenossenschaft, 2013, Bundesverfassung, viewed 21 March 2014 from http://www.admin.ch/opc/en/classified-compilation/19995395/index.html

Schweizerische Eidgenossenschaft, 2015, Konvention zum Schutze der Menschenrechte und Grundfreiheiten, viewed 2 October 2015, from https://www.admin.ch/opc/ de/classified-compilation/19500267/index.html

Schweizerische Eidgenossenschaft, 2016, Bundesamt für Statistik. Religionen, viewed 5 June 2016, from http://www.bfs.admin.ch/bfs/portal/de/index/themen/01/05/ blank/key/religionen.html

Seyyar, A., 2012, 'Seelsorge in islamischer Tradition', in T. Kamran \& G. Wenz (eds.), Seelsorge und Islam in Deutschland, pp. 35-44, Verlagshaus Speyer GmbH, Speyer.

Seyyar, A., 2013, 'Die theoretischen Konzepte der Seelsorge aus islamischer Sicht', in B. Ucar \& M. Blasberg-Kuhnke (eds.), Islamische Seelsorge zwischen Herkunft und Zukunft, pp. 85-100, Peter Lang GmbH, Frankfurt am Main.

Universität Luzern, 2014, Religionen der Schweiz, viewed 2 June 2014, from http:// www.religionenschweiz.ch/religionen.html

Walther, T., 2009, 'Individualization - Migration - Globalization: A Protestant perspective on interfaith spiritual caregiving in the hospitals of Switzerland', in D.S. Schipani \& L. Bueckert (eds.), Interfaith spiritual care: Understandings and practices, pp. 259-278, Pandora Press, Kitchener. 